\title{
RLE-lærere som bibellesere
}

\author{
Av Ole Kolbjørn KJørven
}

In this article I present and discuss the findings from an empirical study on RE teachers as readers and interpreters of religious narratives, in this particular case, the biblical parable The Prodigal Son. I explore and describe the role of the RE teachers and the role of this particular text, and most importantly, the transaction between the two in the process of meaning-making (Rosenblatt, 1994). The main purpose is to expose the complexity in meaning-making processes and from that basis discuss what could be the implications for engaging in religious narratives, and also subject matters in general, in school and in teacher education.

Keywords: Religious education, religious education research, religious literacy, literacy practices, religious education teachers

Ole KolbJørn KJøRven (f. 1969) Førsteamanuensis i religionsdidaktikk ved Høgskolen i Hedmark. Adresse: Hogskolen i Hedmark, Postboks 400, 2418 Elverum.

E-post: ole.kjorven@hihm.no

\section{INNLEDNING}

Vi mennesker leser Bibelen ulikt, om ikke alle "som fanden," som i sitt ordskifte med Jesus i ørkenen åpenbart har en agenda og tar seg sine friheter. ${ }^{1}$ Noen har da også forsøkt å danne seg et bilde av hvordan de fleste av oss, såkalte "normalläsare," leser Bibelen (Svensson, 1989). Dette til tross for at det er vanskelig og også høyst problematisk å operere med kategorier som "normal" og "unormal" i slike sammenhenger. For hva og hvem er en "normal" bibelleser? Da er det bedre å orientere seg mot reelle lesere og lesergrupper, som for eksempel elever i skolen, slik
Miriam R. Opsahl gjorde i sin interessante studie av elevers tolkninger av en bibeltekst (Opsal, 2010).

I skolesammenheng er det påfallende lite som har blitt gjort på lærere som lesere og tolkningsaktører, og dette gjelder ikke bare i forhold til $\mathrm{RLE}^{2}$ og Bibelen spesielt, men skolefagene generelt. ${ }^{3}$ Dette til tross for at det er læreren som legger premissene for undervisningen, og som også fremstår som den sentrale tolkningsaktøren i klasserommet. I tillegg, og da ulikt elever og alle vi andre som gjerne kan fremme private meninger og

1 Matt. 4,.1-11, Mark. 1,.12-13 og Luk. 4,.1-13

2 Jeg bruker ikke KRLE som fagbenevnelse siden studien ble foretatt da faget het RLE i grunnskolen.

3 Den beskjedne innflytelsen forskningsretningen Teachers' Thinking (jf. Shulman \& Shulman, 2008) har hatt innenfor religionsdidaktisk forskning, bekrefter dette inntrykket. Et unntak er forskningsgruppen ved Karlstad Universitet Centrum för de Samhällsvetenskapliga ämnenas Didaktik (CSD), som i god Teachers' Thinking-tradisjon har som målsetting å utvikle en empiribasert "ämnesdidaktik" ved å undersøke sammenhengen mellom læreres fagtenkning og didaktiske tenkning (Schüllerqvist \& Osbeck, 2009). Sammenlignet med dette orienterer min studie seg mer eksklusivt mot RLE-lærere som fagpersoner, som fortolkere av faginnhold. 
tolkninger, er det lærerens jobb å sørge for at undervisningen er i tråd med gjeldende lovog planverk. I et profesjonsperspektiv er det derfor spesielt relevant å sette søkelyset på læreren som fortolker av skolefagenes innhold.

Med forskningsspørsmålet Hvordan tolker RLE-larere den bibelske lignelsen Den bortkomne sønn (Luk 15,11-32)? ønsket jeg å rette søkelyset på nettopp dette. ${ }^{4}$ Analysene og diskusjonen fra undersøkelsen har som mål å bidra til å løfte frem og beskrive hva som former RLE-læreres tolkninger, med den tanken at mer kunnskap om dette vil kunne fremme en mer bevisst og reflektert undervisningspraksis i skole og i utdanning.

\section{Å STUDERE RLE-LÆRERES TOLKNINGER}

Å studere RLE-læreres tolkninger handler om å undersøke medierte tolkninger, basert på den oppfatningen, slik Paul Ricoeur uttrykker det, at "there is no self-understanding that is not mediated by signs, symbols, and texts" (Ricoeur, 1992, s. 15). ${ }^{5}$ Analyseenheten for studien er derfor RLE-lærerresponser. ${ }^{6}$

\section{Leser-responsteori}

A undersøke RLE-lærerresponser førte meg naturlig til leser-responsteori. Forskningsspørsmålet reflekterer at jeg inntok en utforskende og beskrivende tilnærming til RLE-lærerresponsene. Dette bragte meg til den amerikanske teoretikeren Louise M. Rosenblatt og hennes program "Mot dualismene," der hun med referanse til den språklige vendingen i samfunnsvitenskapen og den filosofiske tradisjonen fra Charles S. Peirce, William James og Lev Vygotsky, understreker at all meningsdanning reflekterer en grunnleggende gjensidighet mellom tegn, objekt og interpretant (Rosenblatt, 1994, s. 188). Rosenblatts teori tar derfor avstand fra, på den ene siden, den radikale leserresponsteorien representert ved Stanley Fish, som plasserer meningen i hver enkelt subjektive leser, og på den andre siden, den dominerende litteraturvitenskapelige tradisjonens søken etter objektiv mening og stabil meningsdanning, enten dette forankres i tekstens strukturer (strukturalisme), utenfor teksten i forfatteren og tekstens historiske kontekst (jf. E. D. Hirsch) eller, som hos W. Iser, i tekstens mange åpne rom og negasjoner som "stimulate the process of ideation to be performed by the reader on terms set by the text" (Iser, 1978, s. 169). I stedet må hver lesing forstås, ifølge Rosenblatt, som en unik hendelse og hver leserrespons som en unik ytring, som begge reflekterer "a transaction involving a particular reader and a particular pattern of signs, a text, and occurring at a particular time in a particular context" (Rosenblatt, 2005, s. 7). For å understreke det individuelt unike og også kompleksiteten i det å skape en leserrespons, omtaler Rosenblatt denne prosessen som "fremkalling av et dikt" (Rosenblatt, 1994, s. 48).

En analyse av RLE-læreres tolkninger av Den bortkomne sønn kan på bakgrunn av Rosenblatts transaksjonsteori deles inn i tre deler: For det første handler det om å undersøke betydningen av RLE-læreren som "particular reader" og hva han eller hun bringer på banen av personlige fakto-

\footnotetext{
4 Artikkelen bygger på min avhandling RE teachers' religious literacy: A qualitative analysis of RE teachers' interpretations of the biblical narrative The prodigal son (Kjørven, 2014).

5 I det følgende er lengre engelskspråklige tekstutdrag beholdt, mens ord og begreper er oversatt til norsk av meg. 6 Jon Smidt bruker begrepene "lærerresponser" eller "lærertekster" i sin velkjente leseforskning (Smidt, 1989).
} 
rer (Rosenblatt, 1994, s. 129). Til dette feltet bidrar Stanley Fish og hans forståelse av leserens tilknytning til større "fortolkningsautoriteter" til å utfylle Rosenblatts mer individorienterte perspektiv (Fish, 1980). Men slike fellesskap bør verken oppfattes essensialistisk eller deterministisk, slik Fish's teori tenderer mot. I lærerresponsene vil vi se at tilknytning til en religiøs tradisjon ikke alene kan forklare en lærers respons, like lite som en dominerende skolekultur eller en lærers etnisitet kan gjøre det. Kontekstuelle aspekter som kan virke inn på meningsdanningen, og som manifesterer seg i en respons, viser i stedet sin innflytelse som sosialt generert, men samtidig individuelt internalisert (Rosenblatt, 1998, s. 890). ${ }^{7}$

For det andre handler det om å undersøke betydningen av Den bortkomne sønn som "particular ... text." Ifølge Rosenblatt er det teksten som "trigger” og på grunnleggende vis "guider" leserens meningsdanning (Rosenblatt, 1994, s. 12). Her bidrar Wolfgang Iser og hans forståelse av litterære teksters "respons-inviterende strukturer" til flere analytiske verktøy (Iser, 1974, 1978). Kategorier som “åpne rom” og "negasjoner” som er skapt av for eksempel temaoverganger (eldstesønnens inntreden i fortellingen) eller "kutte-teknikker" som åpne avslutninger (blir den eldste med på festen eller ikke?), belyser hvordan lignelsens strukturer bidrar til å forme RLE-lærerens respons (Iser, 1978, s. 182).

For det tredje, og da til slutt og viktigst, dreier det seg om å forene Fish’ og
Isers perspektiver, altså undersøke en RLElærerrespons som en manifestasjon på transaksjonen mellom en tekst og en leser. For det er der det skjer, i det dynamiske og flytende møtet mellom RLE-læreren og Den bortkomne sønn (Rosenblatt, 1998, s. 887).

\section{Utvalg og materiale}

For å studere RLE-lærerresponser designet jeg en kvalitativ studie der responsene utgjør et "intenst" case-utvalg, det vil si en samling "[i]nformation-rich cases that manifest the phenomenon intensely" (Miles \& Huberman, 1994, s. 28). Informantene, i alt ni kvalifiserte RLE-lærere som underviser regelmessig i faget, ${ }^{8}$ forstås som enkeltstående case. Det betyr at de ikke står som representanter for et typisk eller et gjennomsnittsutvalg av RLE-lærere. Studien gir derfor ikke noe grunnlag for generaliseringer, men i stedet inngående kjennskap til hva som kvalitativt former responsene til dette RLElærerutvalget. Likevel vil jeg hevde at variasjonen og spennet i materialet vil kunne skape gjenklang spesielt blant RLE-lærere med erfaring med denne typen fagstoff. Basert på det Robert Stake omtaler som "naturlig generalisering” (Stake, 1978, s. 7), kan derfor de ni casene oppleves å favne bredere enn hva det kvalitative rammeverket tillater.

For å få tilgang til RLE-lærerresponser ba jeg dem først skrive det jeg kaller individuelle refleksjonstekster, med det formål å gi tid og rom til fordypning og skriving av argumenterende tekster (Eemeren et al., 1996, s. 2). For å få tekster der RLE-lærerne frem-

7 En slik konstruktivistisk kontekstforståelse samsvarer med blant andre Teun van Dijk, slik vi finner det i artikkelen "Discourse, context and cognition" (2006), og i Hilde og G. Afdals artikkel "The hidden context: The dilemma of context in social and educational research" (2010).

8 De ni RLE-lærerne ble rekruttert via rektorer ved såkalte partnerskoler, dvs. skoler i regionene som forplikter seg på å bidra inn mot Høgskolen i Hedmarks utviklings- og forskningsarbeid. Alle lærerne, med unntak av en, hadde 30 stp i faget eller mer. Alle jobbet på barne- og mellomtrinnet og var ansvarlige for minst én klasse i RLE, dvs. at de underviste minimum 1-2 t/uke i faget. 
står som tekstfortolkere og ikke utelukkende metodedidaktikere, noe jeg erfarte i en pilotstudie, poengterte jeg at de skulle konsentrere seg om spørsmålet Hvordan tolker $d u$ Den bortkomne sønn? Dette var naturligvis ikke for å unngå didaktiske elementer, men for å opprettholde et tekstfaglig fokus. Når RLE-læreren som tolkningsaktør står i fokus, er det naturlig nok av stor interesse å se hvordan skolekontekst, erfaringer fra egen undervisning osv. kommer til uttrykk i responsene. Som en del av RLE-lærerkonteksten forstås også dette som noe som fremforhandles av læreren (Van Dijk, 2006, s. 163).

For å få et større materialtilfang gjennomførte jeg individuelle semistrukturerte intervjuer. ${ }^{9}$ Intervju ble også valgt for å komme tettere inn på hvordan RLE-lærere konstruerer mening (Fontana \& Frey, 2005, s. 705; Kvale \& Brinkmann, 2009, s. 3). Spørsmålene tok naturlig nok utgangspunkt i refleksjonsteksten for å gi rom for klargjøringer og utdypinger. Refleksjonsteksten utgjorde derfor en sentral del av konteksten for intervjuet. Intervjuene ses likevel på som likeverdig refleksjonstekstene, basert på den forståelsen at hver refleksjonstekst og hvert intervju representerte en ny og unik hendelse (Rosenblatt, 1994).

\section{NI RLE-LÆRERE, FIRE LESERTYPER} Analysene av RLE-lærerresponsene frembragte fire ulike lesertyper. ${ }^{10}$ To av disse har kun en representant, med den begrunnelsen at begge disse lærerne fremstår som vesensforskjellige i måten de bruker teksten og seg selv i meningsdanningsprosessen. De andre to lesertypene består av to lærere og den siste av fem lærere, noe som da betyr at lærerne innenfor disse lesertypene deler vesentlige indre trekk, såkalt "indre homogenitet," og også “ytre homogenitet," det vil si ytre trekk som skiller dem vesentlig fra de andre (Kluge, 2000). Jeg vil nå presentere de fire lesertypenes karakteristiske trekk.

\section{Den immanente leser}

Den immanente leser har en representant som jeg kaller Terje (54 år). Terje er en erfaren RLE-lærer som underviser primært på mellomtrinnet, og som sammen med en annen lærerinformant har høyest formell kompetanse i faget (90 stp). Men det som dominerer Terjes respons, er ikke referanser til faglig tilegnet kunnskap. Tvert imot, hans anliggende er å fremheve, som han sier, "det som aldri var tema i mine religionsstudier." I tillegg er han kritisk mot kirken som i det store og hele overser det viktigste, nemlig "det menneskelige," i sin formidling. Dette uttrykkes blant annet slik:

Jeg ville bruke medmenneskelighet, sosial tilhørighet, søskenkjerlighet og, ikke sant, til slutt det mest dype ved det hele, nemlig den betingelsesløse kjcrligheten. Det er den veien jeg ville ha gått. For noe annet ville vare helt urimelig synes jeg.

Hvis du går inn den andre gaten der (les: "den guddommelige sfere"), da går vi inn på de umenneskelige sfcerer. Da ligger du på et annet plan enn der jeg arbeider. Det er så abstrakt tenkning. ... For hva er Gud,

\footnotetext{
9 Materialet utgjør til sammen 120 transkriberte sider, hvorav refleksjonstekstene utgjør 18 sider og intervjuene 102 sider.

10 Type (evt. typologi) brukes for klassifiseringer innenfor f.eks. sosialantropologi, psykologi og lingvistikk. Jeg velger likevel å anvende betegnelsen på to lesertyper som begge har kun én representant, dette for å løfte frem det jeg ser er en tydelig indre konsistens i de to lesernes transaksjoner med teksten, noe som da gjør at de tydelig skiller seg ut fra de andre lesertypene. Typebetegnelsen bidrar også til å løfte analysen fra det personlige til et tematisk og dermed også et mer generelt nivå.
} 
for eksempel? Altså, hva er Gud for noe? Det sliter jo antageligvis du med også? Det gjør vi jo alle. Altså, vi har ikke noe bilde av dette. Vi har ingen knagger å henge det på, men vi kan henge det på vår egen far, vår egen mor, våre egne søsken og oss selv.

Poenget til Terje er altså at du som leser må knytte teksten til ditt eget liv, men, og som vi ser, dette avgrenser seg mot det transcendente. For det transcendente oppfattes som utilgjengelig for alle andre bortsett fra "de troende," de som beveger seg i "den guddommelige sfære," som Terje uttrykker det. Derfor, fortsetter Terje, "behøver du ikke bruke noe annet enn den menneskelige dimensjonen $\mathrm{i}$ denne fortellingen og allikevel få frem budskapet." Med andre ord, en strengt immanent tolkning oppfattes av Terje som lignelsens essens.

Det er interessant å se at denne tilnærmingen samsvarer med hvordan Terje også tenker didaktisk. Igjen er Terje krystallklar: "Jeg driver ikke forkynnelse i skolens sammenheng," og henviser til det å snakke om Gud i klasserommet som "urimelig," for, som han sier videre, "elevene har ikke noen abstrakt tenkning." Gud og transcendente perspektiver kan nevnes, men bare som "sånne stikk til slutt" for å informere kort om at "det finnes en sånn kobling."

Terje fremstår på bakgrunn av dette med en tydelig fortolkningsstrategi, det jeg omtaler som en immanent agenda, der han går i rette med etablerte akademiske og også religiøse "fortolkningsautoriteter" (Fish, 1980). Denne agendaen kan spores gjennom hele hans argumentasjon, og som vi ser, også i hans didaktiske tenkning. Men dette undergraver likevel ikke tekstens betydning i meningsdanningsprosessen. Med andre ord, det foregår like fullt en transaksjon mellom Terje og Den bortkomne sønn. Og en transaksjonsanalyse av Terjes respons vil nettopp vise at ulike sider ved tekstens struktur aktivt og på avgjørende vis støtter opp om den immanente argumentasjonen.

Utgangspunktet for Terjes lesing av Den bortkomne sønn er dette: Lignelsen bør leses som et "utviklingspsykologisk" familiedrama der "det som ikke blir fortalt," "det vi ikke får vite noe om" og "det som er skjult" oppfattes som selve saken. For det er her dramaet mellom faren og de to sønnene, og også mellom sønnene, trer fram. Slik kan Terje sette spørsmålstegn ved farens motiv og karakter. Han spør: "Hvor langt strekker nåden seg, egentlig?” Med slike spørsmål ledes leserens blikk vekk fra det forutsigbare og åpenbare; den lykkelige hjemkomsten og den fullkomne forsoningen, og mot spørsmål som disse:

Var det verdt å reise hjem? Eller burde jeg ha dødd der jeg var? Hvor hadde min integritet fått lov til å leve ut? Var det der jeg var å gå til grunne der, som den jeg var, eller å reise hjem og leve $i 40$ år til og gå til grunne der for det jeg har gjort?

For Terje er det opplagt at det er den eldste sønnens hjemkomst som står i fokus og trigger en immanent lesing. Det er her lignelsen gjør et sceneskifte ved anvendelse av "kutteteknikker" og "negasjoner" (Iser, 1978). Med dette vendes fortellingen fra det guddommelige og mot de menneskelige konfliktene der de sanne, menneskelige følelsene kommer til uttrykk. Hvis lignelsen ikke har vært det før, er den nå opplagt i "den menneskelige sfære." Og der blir den, takket være den åpne slutten, som ifølge Terje inviterer leseren til å reflektere over sannsynlige framtidsutsikter. Terje sier dette om faren og den eldste sønnens fremtidige relasjoner til den yngste sønnen: 
Hva var det jeg sa? Men jeg kan godt feste, og jeg kan godt vere glad for at du kom tilbake, men du kommer tilbake som taper fordi $d u$ ikke hørte på meg. Dine feil blir hele tiden holdt pur levende. Du slipper aldri fri. Han slapp aldri fri.

Den yngste sønnen vil nå bli den eldste sønnens slave for han har ingen respekt for sin egen bror lenger.

Lest som et drama drives altså lignelsen fremover av kampen for personlig vinning og reetablering av samfunnets konformitetskrav. I dette spillet fremstår fremfor alt faren som "vinneren," som den "som soler seg i glansen," som Terje uttrykker det.

Denne sterke betoningen av fortellingens siste avsnitt med eldstesønnens hjemkomst og reaksjon, viser at Terjes immanente lesing bærer preg av at han fremhever noen spesielt utvalgte tekstlige strukturer. Selv om Terje er fullt klar over og også jevnlig demonstrerer kunnskap om velkjente genre-spesifikke trekk ved bibelske lignelser, som far-Gud-analogien og spørsmål knyttet til forfatter og adressat, innlemmes ikke dette i Terjes respons. Og forklaringen er enkel: Å vektlegge analogiske og historisk-kritiske aspekter ville undergravet hans immanente agenda.

\section{Den etiske leser}

Den etiske leser har også kun en representant: Peter (37 år). Peter har over 10 års erfaring primært på mellomtrinnet og er godt kvalifisert (60 stp i RLE). En viktig forskjell mellom Peter og Terje er at Peter virker mindre orientert om mulige tolkningsalternativer. Kort sagt, etikk er alt Peter ser. Dette ble synlig da jeg under intervjuet hintet om at han også er inne på å lese et religiøst budskap i teksten da han sa: "Jeg vil også ... legge vekt på at det alltid er plass i det kristne fellesskapet." Men denne koblingen mellom farens hjem og "det kristne fellesskapet," da forstått som kirken, er ikke noe han har vært seg bevisst. Han innrømte: "Det hjelper du meg til å se nå, ser jeg." At etikk forblir det altoverskyggende, kom tydelig frem da han fulgte opp denne tanken videre ved å understreke at kirkens fremste oppgave er å formidle idealet om at "det er alltid plass innunder Jesus og Guds vinger når du selv på en måte er klar til det." Kirken forstås altså som et etisk fundert fellesskap.

Grunnlaget for at den etiske fortolkningsstrategien er så altoverskyggende hos Peter, er dette: Jesus forstås som en etisk veileder, en "rådgiver for sin tid" og "en Sokrates," som han uttrykte det. I dette bildet passer åpenbart Den bortkomne sønn godt, som en tekst som ifølge Peter uttrykker tydeligere enn noen annen bibeltekst hva som ligger i de kristne verdiene "likeverd, menneskesyn, raushet og tilgivelse." Kirkens rolle som "fortolkningsautoritet" blir da å veilede etter de etiske idealene Jesus forkynte (Fish, 1980). Hvis disse verdiene utfordres, som under homofilidebatten der Oslo-biskopene Ole Chr. Kvarme og Gunnar Stålsett representerte to ulike syn, er det all grunn til å rope et varsku. Peter sier det slik:

Kvarme har på en måte gjort at det har gått et skritt i feil retning, rett og slett, for han stiller for mye krav, syns jeg, setter for mye premisser for at det skal vere plass i Den norske kirke, og det tenker jeg at sånn kan det ikke vere.

Peter viser til flere personlige erfaringer som bygger opp under den etiske tilnærmingen. Ved å vise til at han personlig har begått flere "brølere," som han uttrykte det, identifiserer han seg med yngstesønnens "mulighet 
for å kunne begynne på nytt.” I tillegg identifiserer han seg sterkt med det han oppfatter som farens stilltiende imøtekommenhet. $\mathrm{Om}$ dette siste sier han:

Av egen opplevelse har jeg skjønt det at det er ikke sikkert at den innrømmelsen eller den samtalen som ligger i forkant av en eventuell tilgivelse er reell. Jeg tror kanskje ikke på den, altså jeg tror på handlingen fra du sier at du på en måte sier, ok, nå, noe må vi legge bak oss, nå må vi se forover, jeg tilgir deg og du er velkommen hos meg. Det tror jeg i noen situasjoner vil vere det enkleste og kanskje den eneste rette veien å gå, for det er ikke sikkert at du kan få rettet opp alt som er gjort.

Selv om Peter ikke fremstår med en tilsvarende sterk agenda som Terje, finner jeg at det etiske tenkesettet virker som en altoverskyggende fortolkningsstrategi. Og inntrykket, som jeg også fikk av Terje, er at dette er en strategi som anlegges bredt, altså ikke bare på Den bortkomne sønn, men på alle Jesu lignelser, til og med alle Bibelens fortellinger. Men der Terje konfronterte "fortolkningsautoritetene" (Fish, 1989), er Peter av den oppfatning at han fremmer kirkens tradisjonelle budskap. Dette kommer tydelig frem i Peters pedagogiske tenkning, for, som han uttrykte det, det er formidlingen av "de viktigste verdiene kristendommen har ... tilgivelse, nestekjærlighet, romslighet, frastå fra å dømme," som bør stå i sentrum for undervisningen.

En transaksjonsanalyse av Peters respons viser, som vi så det også hos Terje, at han anvender et begrenset utvalg tekststrukturer som på avgjørende vis bygger opp hans argumentasjon. Det mest avgjørende er at Peter leser Den bortkomne sønn som en eksempelfortelling der, som han uttrykker det, karakterene spiller ut "de viktigste verdiene kristendommen har.” Mens faren fremstår som et farsideal som alle fedre bør etterligne, som den som uforbeholdent tar imot og tilgir, illustrerer de to sønnene andre sider ved "menneskets natur." Dette sier han om den eldste:

Han har ikke de samme egenskapene som sin far, tenker jeg. Han er litt mer sånn innad, sentrert mot seg selv, opptatt av hva han har prestert og vil gjerne ha igjen litte granne credit for det, få et klapp på skuldra for det. Men samtidig så ser jeg jo noen egenskaper som ligger i menneskets natur.

I tillegg er Jesu rolle som forteller i lignelsen en nøkkel for Peter. Med referanse til åpningsordene "Jesus sa:" (Luk 15,11), så er det opplagt for Peter at det er den historiske fortelleren som trer frem, og det med "overveldende overlegenhet,” for å bruke Isers begreper om fortellerstemmens potensial som meningsskapende struktur (Iser, 1974, s. 110). Denne sammenstillingen av Jesus som historisk forteller og hvordan han oppfatter Jesus som "rådgiver for sin tid" og "en Sokrates," gir naturlig nok styrke til den eksklusive etiske tilnærmingen.

Det er altså ingenting i lignelsen som utfordrer Peters etiske tilnærming. Men, og som jeg var inne på tidligere, så er det ikke noe $\mathrm{i}$ hans lesing som tilsier at han bevisst velger bort eller unngår tekstlige strukturer som kan utfordre en slik lesing. Jeg finner altså ikke at han polemiserer for ett bestemt syn, slik jeg fant det hos Terje. I stedet finner jeg en transaksjonsprosess som kjennetegnes ved at et begrenset antall tekstlige strukturer faller på plass innunder et overordnet etisk rammeverk. Men resultatet blir, som vi så det hos Terje, en respons som orienterer seg mot det ene store temaet. 


\section{Den kristne leser}

Ordet kristen er ikke brukt for å plassere disse lærerne trosmessig, det til tross for at alle disse lærerne (5) ga inntrykk av at de mer eller mindre gjennom livet har hatt en positiv tilknytning til kristendommen og kirken. Men dette gjelder ikke bare disse lærerne. Kristen understreker i stedet at deres responser preges av kirkens autoritet som fortolkende fellesskap (Fish, 1980). Referanser til "hvordan jeg alltid har tenkt om disse tingene," "hva jeg har blitt fortalt," og også kommentarer som "at dette er kirkens budskap," "kristendommens kjerne” og "vår tro," gir inntrykk av at disse lærerne forholder seg til, og da ulikt Terje, en mer kollektiv fortolkningsautoritet

Noe som illustrerer det kollektive, er at lærerne gir inntrykk av at de er forpliktet på, i enkelte tilfeller også bundet til, en bestemt forståelse. En av disse lærerne, Elise, ga tydelige signaler om dette da hun under intervjuet avstod fra å gå videre på en tankerekke som åpenbart utfordret hennes tolkningsrom. Tydelig noe ukomfortabel med situasjonen sa hun dette da hun begynte å reflektere mer fritt over eldstesønnens forhold til det å være hjemme i "farshuset": "Nå begynner jeg vel å tolke mye mer enn det som står der da."

Denne fortolkningsstrategien ansporer til det flere av disse lærerne uttrykker er "den opplagte meningen med teksten," da med referanse til et helhetlig bilde av hva den kristne tro handler om. Dette kom til uttrykk på to måter. En måte var at teksten leses kristologisk og knyttes eksplisitt til Jesu frelsesverk. Elin uttrykte dette slik:

Det Jesus forteller her, det har $i$ veldig stor grad noe med Jesu eget liv å gjøre. At det var han som åpnet opp for denne tilgivelsen ... at Jesus selv sonet for menneskenes synd slik at nåde og tilgivelse ble 'varemerket til kristendommen.'
Anne kom inn på det samme da hun poengterte i sin refleksjonstekst det hun mener er essensen i "Kristendommens lære”:

Kristendommens lare: Menneskene får tilgivelse for sine synder, hvis de ber om tilgivelse og vender om - tar avstand fra de gale handlingene de har gjort og starter opp å leve slik Gud har sagt vi skal leve. Denne tilgivelsen kan menneskene få fordi Jesus har tatt på seg alle menneskenes synder, og det kunne han gjøre siden han hadde levd et syndfritt liv.

At velkjent kristen dogmatikk var en dominerende faktor, kom tydelig til uttrykk da Anne under intervjuet kommenterte at en slik forståelse "egentlig ikke" har så mye med Den bortkomne sønn å gjøre:

Altså, det går egentlig ikke på historien, men ... Gud kan tilgi alle mennesker det de har gjort ... Det å tilgi er på en måte en slags gave. Men du kan på en måte ikke gjøre det på vegne av andre. Men det kan Gud, på et vis, fordi at han hadde en sønn som har på et vis tatt på seg alle menneskers synder.

Den andre måten den kollektive kristne fortolkningsstrategien kom til uttrykk på, var oppfatningen av Den bortkomne sønn som den ultimate kristne omvendelsesfortellingen. Fremfor noen andre bibeltekster illustrerer denne teksten selve kjernen; om menneskets syndighet og behov for omvendelse, og om Guds kjærlighet og uforbeholdne tilgivelse. Elise uttrykte dette slik: "Slik er Gud i kristen forståelse, som en god far, og slik tar han imot dem som kommer tilbake. Gud er kjærlighet, og han tilgir den som 'vender om."

Et fremtredende aspekt ved den kristne lesingen er at til tross for at alle lærerne under- 
streket det uforbeholdne, så knyttes omvendelse nøye til endring av livsførsel, til det å gå fra umoralsk livsførsel og til, som lærerne uttrykte det, et "guddommelig" eller et "kristent liv" som er "i tråd med Guds vilje." Det å være kristen og da også innenfor det kollektive kristne fellesskapet, blir altså tydelig forbundet med moralske egenskaper og markører.

Vi ser altså at en kristen lesing bygger på det som gjerne omtales som kristen allegorisering (jf. Kermode, 1979). En transaksjonsanalyse viser at fundamentet for en slik lesing er far-Gud-analogien. Det er umulig å overse dette, ifølge disse lærerne. Ved å lese Den bortkomne sønn slik Terje og Peter gjorde, altså vektlegge det immanente og det etiske, så fjerner man seg fra tekstens kjerne. Da fremstår teksten, som Rita uttrykte det $\mathrm{i}$ intervjuet, som "da-ba-da-ba-da-ba-da," altså ganske så flat, ja nærmest verdiløs.

Kristen allegorisering baserer seg videre på en klar fremheving av den yngste sønnen. Dette er hovedaktøren i fortellingen siden det er han som spiller ut den kristne omvendelseshistorien: Han er den som forlater Gud og dermed ødelegger sitt liv, for så å vende tilbake som en angrende synder.

Også tittelen Den bortkomne sønn som tekstlig struktur bidrar vesentlig til å rette søkelyset på den yngste. Og inntrykket som gis, er at tittelen ga fasiten og nærmest gjorde det unødvendig å fokusere på noe annet, med det resultat at den eldste sønnen og det siste avsnittet $i$ lignelsen fikk liten eller ingen omtale. Marie nevner ikke den eldste sønnen i sitt refleksjonsnotat, og sa også i intervjuet at "han har jeg ikke tenkt så mye på." Med yngstesønnens hjemkomst og ordene "Så begynte festen og gleden" i vers 24 , så er alt det vesentlige sagt. Det siste avsnittet kunne altså vært utelatt uten at det hadde fått noen innvirkning på tolkningen.
Selv om Elin reflekterte noe over eldstesønnen, fant heller ikke hun denne karakteren spesielt interessant siden han som "kristen," som "døpt" og "troende" oppfattes som en som "ikke har noen spesielle religiøse problemer," som hun uttrykte det. Derfor sier hun:

Han retter seg jo etter faren, regner jeg med, selv om det kanskje ikke står det. Det blir jo fest og det blir glede, så da regner jeg med at hadde det vert noe mer kroll så hadde det stätt noe mer om den eldste sønnen.

Ilikhet med Peters etiske lesing, finner jeg ikke en bevisst utelukkelse av tekstlige strukturer i den kristne lesingen, men heller en tilpasning som gjør at alt finner sin plass innenfor det en kristen allegorisering gir rom for. Rita viser hvor dominerende denne allegoriseringsformen er når hun reflekterer kort over den eldste sønnens reaksjon. Hun innrømmer at hun blir noe forvirret når den eldste blir sjalu, siden dette passer dårlig med det bildet hun har av kristne. Hun sier:

For vi (les: kristne) misunner jo ikke eller blir ikke sjalu på dem som har levd et utsvevende liv og blir kristne, vi blir jo ikke sjalu på dem ... vi er jo glad for dem som kommer tilbake til Farshuset uansett, i livet, og uansett hvilket tidligere liv de har levd.

Men til tross for denne lille forvirringen så skaper ikke det et incitament for å utforske andre tolkningsmuligheter. Til det er den kristne allegoriseringen for dominerende. I likhet med den immanente og den etiske leser så ser vi altså at også den kristne leseren orienterer seg mot det ene store temaet. 


\section{Den dialogiske leser}

Jeg beskriver to RLE-lærere som dialogiske lesere: Karianne (63 år) og Hanne (53 år). Begge har lang erfaring fra skolen. Sammen med Terje er Karianne den med høyest formell kompetanse blant RLE-lærerne (90 stp). Hun har også undervist i faget hele sin karriere på alle nivåer i barneskolen. Hanne, derimot, er både formelt ukvalifisert (7 1/2 stp) og helt fersk som ansvarlig for RLE-undervisningen. Til tross for disse ulikhetene fremstår de like i sin tilnærming til Den bortkomne sønn.

Begrepet dialogisk uttrykker at lesertilnærmingen kjennetegnes av et fremtredende samspill mellom leser og tekst. Ved første øyekast kan spesielt Kariannes respons oppfattes tekstsentrert. Med uttalelsen: "Er det noen annen måte å forstå denne teksten på?” synes det som om teksten leder leseren mot den ene opplagte tolkningen. Men en transaksjonsanalyse viser at Karianne, og også Hanne, bruker et bredt spekter av tekstlige strukturer på en måte som aktivt inviterer leseren til å bringe inn ulike "personlige faktorer" i tolkningsarbeidet (Rosenblatt, 1994, s. 129).

For Karianne og Hanne er Gud-faranalogien tekstens nøkkelstruktur, forstått slik at faren i teksten viser hvem Gud er, og også hva som kjennetegner Gud-menneskerelasjonen. I likhet med en kristen lesing er derfor også Karianne og Hanne av den oppfatning at en etisk og immanent lesing ikke vil kunne gripe lignelsens kjerne. Men, og da ulik en kristen lesing, danner ikke en kristen allegorisering rammeverket for tolkningen. I stedet er det analogien og den eldste og den yngste sønnens relasjon til Gud som blir stående i sentrum, og som da danner grunnlaget for den dialogiske tilnærmingen. Hanne uttrykker dette ved å fremheve de to sønnenes liv som et uttrykk for det spennet alle mennesker lever i, nemlig "tilstanden mellom tillit og mistillit" og mellom "tro og ikke tro."

Ilikhet med Terjes immanente tilnærming så er det det siste avsnittets vending og åpne slutt som virkelig utfordrer og inviterer lesere til å gå i dialog med teksten (Iser, 1974). Men, og da forskjellig fra Terje, så ligger analogien til grunn. At den "guddommelige sfære" ikke blir irrelevant for den "menneskelige sfære," kommer tydelig til uttrykk når Karianne og Hanne blir følelsesladete og dypt engasjerte når de reflekterer over hva det kan bety å være bortkommen og det å være hjemme. Karianne viser i dette utdraget av intervjuet hvordan hun bruker sin katolske bakgrunn for å reflektere rundt det å være hjemme, altså nær Gud:

Er det en litt sånn mistillit helt $i$ bunnen? ... Altså den der tvilen fordi Gud aldri har sagt tydelig til deg: Jeg ser deg, jeg elsker deg, ikke sant, som han gjør overfor den andre. Og at vi da på en måte blir litt usikre da. Nei for jeg, altså jeg er katolikk, da, så jeg er midt inni helgenene (ler litt). Ikke så veldig mye men, men jeg tenker liksom, det undrer meg at de kan komme til så mye tvil, og da har jeg har tenkt det er kanskje at de har alltid vandret der og er så ncere, og så er den tvilen der.

Det å leve "så nære" forstås altså ikke innenfor rammen av kirken som fortolkningsfellesskap (Fish, 1980), men i stedet relasjonelt. Slik går Karianne og Hanne inn i en mer subjektivleserinvolvering, men, og da ulikt Terjes psykologiske lesing, en tekstsentrert leserinvolvering der analogien og møtet mellom "den guddommelige" og "den menneskelige sfære" forblir hovedtemaet.

I motsetning til de andre lesertypene fremstår Karianne og Hanne som lesere som går frem og tilbake mellom det personlige og subjektive på den ene siden og sentrale tekst- 
lige strukturer på den andre. Gjennomgående i sine responser siteres lignelsen, og da lignelsen mer som en helhet, samtidig som de stiller spørsmål til teksten der deres egne erfaringer trekkes inn som relevante referanser. Dette skaper en tekst-leser-dialog som, for å bruke Rosenblatt, "constantly vibrates between the pole of the text and the pole of his own responses to it" (Rosenblatt, 1994, s. 129). Dermed ender ikke den dialogiske tilnærmingen med å argumentere for det ene store temaet, men i stedet eksplorerende, med å stille spørsmål og åpne opp for "nye lesinger," "justering av mening," og også, men da innenfor hva det analogiske rammeverket tillater, "revisjon av fortolkningsrammeverk" (Rosenblatt, 1994, s. 11; 54).

\section{UTSYN MOT RLE I SKOLE OG UTDANNING}

For å starte med det minst overraskende: RLE-læreren som leser spiller en avgjørende rolle for tolkningen av Den bortkomne sønn. Dette kan kanskje oppfattes som unødvendig å nevne, men den sterke tradisjonen for å usynliggjøre leseren ved å fremheve forfatterspørsmål (historisk-kritiske tenkning) og teksters meningsskapende strukturer (f.eks. formalisme) både innenfor teologi og i litteraturvitenskapen, gjør det viktig å påpeke dette. Også den begrensede interessen for lærerens forståelse av fagstoff innenfor skoleforskningen, slik jeg påpekte innledningsvis, viser at det er viktig å nevne det helt innlysende. Uten godt empirisk grunnlag lar jeg det stå åpent om ikke Rosenblatts beskrivelse av "Den usynlige leseren" 11 i litteraturundervisningen i USA gjenspeiler situasjonen også i mange RLE-klasserom.
For å underbygge dette med lærerens rolle kan det også henvises til John Hattie og hans 800 metaanalyser, som i sine konklusjoner vektlegger "the importance of educators as evaluators of their impact" (Hattie, 2012, forord). Men mens Hattie konstaterer og diskuterer dette på bakgrunn av kvantitative data, kan denne studien bidra til en mer dyptgripende diskusjon om læreres faktiske "impact" og hvordan dette former og blir formet av konkret lærestoff. Jeg vil derfor avslutte med å trekke frem tre punkter som fremstår som spesielt betydningsfulle i RLE-lærernes transaksjoner med Den bortkomne sønn. Disse punktene oppsummerer samtidig hovedtrekkene ved de fire lesertypene:

1 Tekstsentrering: I hvilken grad og på hvilken måte anvendes tekstens ulike strukturer? Velger læreren ut en liten del, eller brukes 'hele' teksten? I min studie fremstår den immanente, men også den etiske og den kristne leseren, som mer selektive enn den dialogiske leseren.

2 Leserinvolvering: I hvilken grad og på hvilken måte bruker læreren sin erfaring og bakgrunn? Anvendes dette som tolkningsnøkkel eller referansepunkt, altså som det som forklarer teksten, eller som noe som inngår i en samtale med teksten? Igjen så vi at den immanente, den kristne og den etiske leseren, til forskjell fra den dialogiske leseren, preges av at personlige (immanente) eller kollektive (etiske og kristne) fortolkningsstrategier langt på vei styrer tolkningene.

3 Tekst-leser-samspillet: Hvordan er forholdet mellom tekst og leser? Tolkningen styres ikke av teksten alene, som om Den bortkomne sønn geleider RLE-læreren mot en opplagt tolkning. Tolkningen 
styres heller ikke alene av RLE-lærerens relasjoner til etablerte akademiske og/ eller religiøse "fortolkningsautoriteter" (Fish, 1980). For det er ikke tekst-leserdikotomien som på grunnleggende vis kjennetegner Terje og Peter som immanente og etiske lesere, eller som forener Karianne og Hanne som dialogiske lesere, ei heller de fem kristne lesertypene. Det som viser seg mest avgjørende, er i stedet de mer eller mindre bevisste beslutningene som tas knyttet til tekstsentrering og leserinvolvering, og hvordan disse beslutningene gjensidig påvirker hverandre.

På bakgrunn av dette vil jeg hevde at det er viktig at lærere og også elever tilegner seg kunnskap om og også evne til å reflektere kritisk over deres møte med fagstoff. Med støtte i Rosenblatt handler dette også om noe større, at oppøving av kritisk refleksjon og tilegnelse av kunnskap om hvordan mening dannes, "serve the purposes of education for democracy" (Karolides, 1999, s. 169). En kvalitativ studie av Hvordan RLE-lerere tolker Den bortkomne sønn? kan derfor også bidra med viktige innspill i andre debatter, blant annet den nasjonale og internasjonale diskusjonen om litterasitet i skolens fag (jf. Moore, 2007; Kleve, 2014; Kjørven, u.a.).

\section{LITTERATUR}

Afdal, H. W., \& Afdal, G. 2010. The hidden context: The dilemma of context in social and educational research. I S. Kvam, K.P. Knutsen og P. Langemeyer (red.), Textsorten Und Kulturelle Kompetenz: Interdisziplinare Beitrage Zur Textwissenschaft (s. 51-70). Münster: Waxmann.
Eemeren, F.H. v., Henkemans, F.S., og Grootendorst, R. 1996. Fundamentals of argumentation theory: A handbook of historical backgrounds and contemporary developments. Mahwah, N.J.: L. Erlbaum.

Fish, S.E. 1980. Is there a text in this class? The authority of interpretive communities. Cambridge, Mass.: Harvard University Press.

Fontana, A. og Frey, J.H. 2005. The interview: From neutral stance to political involvement. In N. K. Denzin \& Y. S. Lincoln (Eds.), The Sage handbook of qualitative research (s. 695-728). Thousand Oaks, Calif.: Sage.

Hattie, J. 2012. Visible learning for teachers: Maximizing impact on learning. London: Routledge.

Iser, W. 1974. The implied reader: Patterns of communication in prose fiction from Bunyan to Beckett. London: John Hopkins University Press.

Iser, W. 1978. The act of reading: A theory of aesthetic response. Baltimore: John Hopkins University Press.

Karolides, N.J. 1999. Theory and practice: An interview with Louise M. Rosenblatt. Language Arts, 77(2), 158-170.

Kermode, F. 1979. The Genesis of Secrecy: On the Interpretation of Narrative. Cambridge: Harvard University.

Kjørven, O.K. 2014. RE teachers' religious literacy: a qualitative analysis of $R E$ teachers' interpretations of the biblical narrative The Prodigal Son. (Avhandling), [Oslo]: Det teologiske menighetsfakultet.

Kjørven, O. K. (u.a). The discourse on religious literacy and the implications of empirical research. I Engen, T.O., Kulbrandstad, L.A., Lied, S. (red.) Education and diversity Norwegian perspectives. Cambrigde Scholars Publishing. 
Kleve, B., Penne, S. og Skaar, H. 2014. Literacy og fagdidaktikk $i$ skole og lcererutdanning. Oslo: Novus.

Kluge, S. 2000. Empirically grounded construction of types and typologies in qualitative social research. I Forum: Qualitative Social Research. Nedlastet 08.23.2013, fra http:// www.qualitative-research.net/index.php/ fqs/article/view/1124/2499

Kvale, S., og Brinkmann, S. 2009. Interviews: Learning the craft of qualitative research interviewing (2nd ed.). Los Angeles, Calif.: Sage.

Miles, M.B. og Huberman, A.M. 1994. Qualitative data analysis: An expanded sourcebook. Thousand Oaks, Calif.: Sage.

Moore, D.L. 2007. Overcoming religious illiteracy: A cultural studies approach to the study of religion in secondary education. New York: Palgrave MacMillan.

Opsal, M.R. 2010. "Lillebror får det som han vil": En empirisk studie av responser fra elever $i$ den videregående skole på fortellingen fra Lukas 15, 11-32, sett $i$ lys av Mikhail M. Bakhtin språkfilosofi og religionsdidaktisk teori. (Masteroppgave). Oslo: Universitetet i Oslo.

Ricoeur, P. 1992. Oneself as another. Chicago: University of Chicago Press.

Roen, D. og Karolides, N. 2005. Louise Rosenblatt: A life in literacy. The Alan Review (Summer), 59-61.
Rosenblatt, L.M. 1994. The reader the text the poem: The transactional theory of the literary work. Carbondale: Southern Illinois University Press.

Rosenblatt, L.M. 1998. Readers, texts, authors. Transactions of the Charles S. Peirce Society: A quarterly journal in American philosophy 34(4), 885-921.

Rosenblatt, L.M. 2005. From "The Poem as Event”. Voices from the Middle, 12(3), 48-50.

Schüllerqvist, B. og Osbeck, C. 2009. Ämnesdidaktiska insikter och strategier: Berättelser från gymnasielärare i samhällskunskap, geografi, historia och religionskunskap. Karlstad: Karlstad University Press.

Shulman, L.S. og Shulman, J.H. 2008. How and what teachers learn: A shifting perspective. Journal of Education, 189(1/2), 1-8.

Smidt, J. 1989. Seks lesere på skolen: Hva de søkte, hva de fant. Oslo: Universitetsforlaget.

Stake, R.E. 1978. The case study method in social inquiry. Educational Researcher, 7(2), 5-8.

Svensson, C. 1989. Text och tro: Hur läsare skapar mening i bibeltexter. Örebro: Libris.

Van Dijk, T.A. 2006. Discourse, context and cognition. Discourse Studies, 8(1), 159-177. doi: $10.1177 / 1461445606059565$ 